\title{
Author Correction: Identification of TC2N as a novel promising suppressor of PI3K-AKT signaling in breast cancer
}

Xiang-lin Hao (1)', Li-yun Gao ${ }^{2,3}$, Xiao-juan Deng ${ }^{1}$, Fei Han ${ }^{1}$, Hong-qiang Chen ${ }^{1}$, Xiao Jiang ${ }^{1}$, Wen-bin Liu' Dan-dan Wang ${ }^{1}$, Jian-ping Chen ${ }^{1}$, Zhi-hong Cui ${ }^{1}$, Lin Ao ${ }^{1}$, Jia Cao ${ }^{1}$ and Jin-yi Liu (1) ${ }^{1}$

\section{Correction to: Cell Death \& Disease}

https://doi.org/10.1038/s41419-019-1663-5

Published online 29 May 2019

After publication of this article, it came to the attention of the authors that their names had been reordered. Professor. Jia Cao and Prof. Jin-yi Liu are the co- corresponding authors, and Prof. Jin-yi Liu should be the last author.

This has been corrected in both the PDF and HTML versions of the Article.

Published online: 24 June 2019

Correspondence: Jia Cao (caojia1962@126.com) or

Jin-yi Liu (jinyiliutmmu@163.com)

${ }^{1}$ Institute of Toxicology, College of Preventive Medicine, Third Military Medical

University, Chongqing 400038, PR China

${ }^{2}$ School of Public Health, Xinxiang Medical University, Xinxiang, PR China

${ }^{3}$ Cooperative innovation center of molecular diagnosis and medical inspection technology, Beijing, PR China

Edited by A. Stephanou

(C) The Author(s) 2019

(c) Open Access This article is licensed under a Creative Commons Attribution 4.0 International License, which permits use, sharing, adaptation, distribution and reproduction C. in any medium or format, as long as you give appropriate credit to the original author(s) and the source, provide a link to the Creative Commons license, and indicate if changes were made. The images or other third party material in this article are included in the article's Creative Commons license, unless indicated otherwise in a credit line to the material. If material is not included in the article's Creative Commons license and your intended use is not permitted by statutory regulation or exceeds the permitted use, you will need to obtain permission directly from the copyright holder. To view a copy of this license, visit http://creativecommons.org/licenses/by/4.0/. 